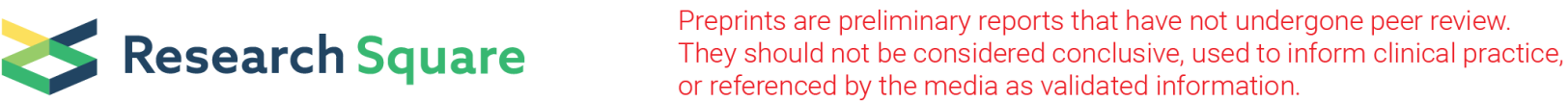

\section{When Did the Chicken Cross the Road: Archaeological and molecular evidence for ancient chickens in Central Asia}

Robert Spengler ( $\nabla$ spengler@shh.mpg.de)

Max Planck Institute for the Science of Human History https://orcid.org/0000-0002-5648-6930

Carli Peters

Max Planck Institute for the Science of Human History

Kristine Richter

Max Planck Institute for the Science of Human History

Basira Mir-Makhamad

Max Planck Institute for the Science of Human History

\section{Sören Stark}

Institute for the Study of the Ancient World, New York University

\section{Ricardo Fernandes}

Max Planck Institute for the Science of Human History

\section{Farhad Maksudov}

Institute of Archaeology, Uzbek Academy of Sciences

Mirzaakhmedov Sirojidin

Institute of Archaeology, Uzbek Academy of Sciences

Rahmonov Husniddin

Institute of Archaeology, Uzbek Academy of Sciences

Shevan Wilkin

University of Zurich

\section{Stefanie Schirmer}

Max Planck Institute for the Science of Human History

\section{Kseniia Ashastina}

Max Planck Institute for the Science of Human History

\section{Alisher Begmatov}

Berlin-Brandenburg Academy of Sciences and Humanities

\section{Michael Frachetti}

https://orcid.org/0000-0001-6906-4334

\section{Taylor Hermes}

Max Planck Institute for Evolutionary Anthropology https://orcid.org/0000-0002-8377-468X 
New York University Abu Dhabi

\section{Andrey Omelchenko}

State Hermitage Museum

\section{Barbara Huber}

Max Planck Institute for the Science of Human History

\section{Nicole Boivin}

Max Planck Institute for the Science of Human History https://orcid.org/0000-0002-7783-4199

\section{Shujing Wang}

School of Art and Archaeology, Zhejiang University

\section{Pavel Lurje}

State Hermitage Museum

\section{Madelynn von Baeyer}

Max Planck Institute for the Science of Human History

\section{Rita Dal Martello}

Max Planck Institute for the Science of Human History

\section{Social Sciences - Article}

Keywords: Chicken, Poultry, Eggs, Eggshell, Zooarchaeology, Peptide mass fingerprinting, Zoroastrian, Hellenistic

Posted Date: February 14th, 2022

DOI: https://doi.org/10.21203/rs.3.rs-1340382/v1

License: (c) (i) This work is licensed under a Creative Commons Attribution 4.0 International License. Read Full License 


\section{Abstract}

The origins and dispersal of the chicken across the ancient world remains one of the most enigmatic questions regarding Eurasian domesticated animals1,2. The lack of agreement regarding the timing and center of origin is due, in large part, to issues with morphological identifications, a lack of direct dating, and poor preservation of thin bird bones. Historical sources attest to the prominence of chickens in southern Europe and southwest Asia by the last centuries BC3. Likewise, art historical depictions of chickens and anthropomorphic rooster-human chimeras are reoccurring motifs in Central Asian prehistoric and historic traditions4-6. However, when this ritually and economically significant bird spread along the trans-Eurasian exchange routes has remained a mystery. Here we show that chickens were widely raised by people at villages across southern Central Asia from the third century BC through medieval periods for their eggs and likely also meat. In this study, we present archaeological and molecular evidence for the cultivation of chickens for egg production from 12 different Central Asian archaeological sites spanning a millennium and a half. These eggshells were recovered in high abundance at all of these sites, suggesting that chickens were widely raised by people at villages across southern Central Asia from the third century BC through medieval periods and that they were an important part of the overall diet. Contrary to views that ancient peoples of Central Asia were primarily herding sheep, goat, and cattle, these data show that chicken was also important in the subsistence economy and that it was widely spread along the ancient Silk Road.

\section{Introduction}

Debate over the origin(s) and spread of domesticated chickens (Gallus gallus spp. domesticus) has intensified in recent years with the introduction of genetic and molecular methods, reigniting old controversies over the enigmatic bird. For a summary of the domestication debates, as they currently stand, see Supplementary Discussion 1. Specialists agree that domestication traits evolved in the South Asian red jungle fowl (possibly involving hybrids of subspecies) somewhere across its expansive range from Thailand to India. Scholars have also argued for widely diverging dates and routes of spread, and some of this confusion comes from unclear identifications of birds in ancient art historical depictions ${ }^{3}$ and overlap in morphological features of chicken bones with those of certain wild avian species. Additionally, brittle hollow bones and eggshells are far less likely to be preserved, recovered, and identified than those of other animals ${ }^{7}$. Further blurring the narrative of the early stages of chicken spread is the fact that pheasants (Phasianidae) and ducks (Anatidae) in China and geese (Alopochen aegyptiaca) in Egypt have, at times in the ancient past, been cultivated or heavily hunted. Biomolecular techniques, such as peptide mass fingerprinting and ancient DNA are uniquely poised to overcome these taphonomic and morphological obstacles to clarify one of the greatest remaining mysteries in the domestication and spread of Old World animals. In this manuscript, we illustrate the success of combining morphological analysis and peptide mass fingerprinting by identifying ancient chicken eggshell fragments from twelve archaeological sites in Central Asia spanning ca. 300 BC to AD 1220. The lack of eggshells from any older Central Asian archaeological sites hints to a rapid rise of egg-laying and chicken rearing across 
Hellenistic and Zoroastrian West Asia, an economic tradition that appears to have remained prominent through the medieval period in this part of the world.

In a large-scale reassessment of the zooarchaeological material from the southern Levant, Perry-Gal et al. ${ }^{1}$ argued that chickens occupied a symbolic and social domain prior to the Hellenistic period (fourth to second centuries $\mathrm{BC}$ ), after which point their bones sharply rise in ubiquity and abundance in archaeological assemblages. One often-propagated claim is that the chicken served an entertainment role in cock fights before it took on its significant economic status, and some scholars have hypothesized that breeding sports birds may have segued into their role as food ${ }^{8,9}$. Historians have also suggested that the birds were a sacrificial animal for divination or an elite commodity for their plumage and as live caged displays prior to their rapid dispersal across West Asia ${ }^{10}$. They maintained a ritual role into the Roman period as attested from Classical texts and archaeological contexts. For example, at a second century AD shrine to Mithras in Germany an assemblage of more than 7,500 chicken remains was recovered ${ }^{11}$ (the linkage between the chicken and a deity associated with Persian origins is unlikely to be a coincidence). Cicero mentioned their power of divination in De Divinatione ${ }^{12}$. The imagery of cock fighting also continued into the Greco-Roman period and accounts for many of the earliest chicken images in the Mediterranean, such as on coins from the Temple of Artemis at Ephesus, estimated to date to $625-600 \mathrm{BC}^{9}$.

The sudden cultural shift in the role of the chicken to an important food source across the ancient world may have been tied into the development of more prolific egg-laying phenotypes. In this article, we present new evidence for a prominence of chicken egg production in Central Asia starting in the last centuries $\mathrm{BC}$ and continuing into the medieval period. The archaeological data that we present consist of fragments $(1.5-4.0 \mathrm{~mm})$ of eggshells recovered from sediments in archaeological contexts at the core of the ancient Silk Road trade routes. The data come from Bash Tepa, an Hellenistic fortified site on the edge of the Bukhara Oasis (ca. $3^{\text {rd }}$ century $B C-1^{\text {st }}$ century $A D$ ), several occupation layers at Paykend dated from the Hellenistic (ca. $3^{\text {rd }}-2^{\text {nd }}$ centuries $B C$ ) to medieval period $\left(10^{\text {th }}-12^{\text {th }}\right.$ centuries $\left.A D\right)$, the medieval cities of Kafir Kala $\left(7^{\text {th }}-9^{\text {th }}\right.$ centuries AD), Bukhara $\left(9^{\text {th }}-11^{\text {th }}\right.$ centuries AD), Afrasiab $\left(10^{\text {th }}-\right.$ $12^{\text {th }}$ centuries $A D$ ), ancient Panjikent (citadel and main town, $5^{\text {th }}-8^{\text {th }}$ centuries $A D$ ), Kok-Tosh or preMongol Panjakent ( $9^{\text {th }}-12^{\text {th }}$ centuries $\left.A D\right)$, Sanjar-Shah settlement $\left(5^{\text {th }}-9^{\text {th }}\right.$ centuries $\left.A D\right)$ and the highelevation urban site of Tashbulak ( $10^{\text {th }}-12^{\text {th }}$ centuries $\left.A D\right)$. We propose two hypotheses: 1$)$ the rapid and widespread dispersal of chickens across the ancient world during the last centuries BC coincided with greater egg producing variants; and 2) poultry farming and egg production were an important and regular part of the economy in villages and urban sites across Central Asia from the Hellenistic through at least the Qarakhanid periods.

\section{Rapid Dissemination across the Ancient World}

Zooarchaeologists claim to have identified domesticated chickens at a handful of southwest Asian sites from contexts dating to the late second and early first millennia $\mathrm{BC}^{2,13}$ (see Supplementary Discussion 2). 
However, these finds consist of one or two bones in assemblages of tens of thousands of animal bones. The earliest sites with identifiable chicken bones that appear in abundance are Tel Kedesh (last centuries $\left.B C^{2}\right)$ and Maresha $\left(4^{\text {th }}-2^{\text {nd }}\right.$ centuries $\left.B C^{1}\right)$, both in Israel (Figure 1). Shortly thereafter, the bird is reported from archaeological sites in Japan and Korea - the Yayoi period (ca. 300BC - AD300 ${ }^{13}$ ) and in England by the first centuries $A D^{14}$. One argument suggests that the species rapidly disseminated with the Macedonian expansion, another suggests that the expansion of the Persian Empire by Cyrus in 539 $\mathrm{BC}$ opened the long-distance exchange networks that allowed the chicken to cross the world ${ }^{7}$. Much of the contention over the earliest spread of chickens has focused on the reliability of pre-Hellenistic reports of the bird. For example, there have been many claims of pre-Ptolemaic chickens in Egypt, but the earliest indisputable evidence comes from the last centuries $\mathrm{BC}^{15}$. Fascinatingly, the chicken appears to have spread via coastal routes to Central Africa prior to its dispersal in Egypt ${ }^{16}$. There are also a handful of early reports of chicken bones in Europe, pre-dating the Roman expansions. Historians have suggested that the chicken spread through the Mediterranean with Phoenician traders during the mid-first millennium BC, rising to prominence in the Greco-Roman period, when specialized poultry farms developed for the first time ${ }^{17,18}$. Chicken bones are a common feature at nearly all Roman sites, including ritual centers, villages, and farmsteads (Figure 1), and the Classical importance of chickens is well attested in textual sources.

\section{Results}

\section{Archaeological Eggshells}

Eggshells were recovered from all archaeological sites from central and southern Central Asia dating to later than the third century BC that our team has examined thus far. Additionally, shell fragments remain absent from any earlier occupation sites (bearing in mind that absence of evidence is not necessarily evidence for absence). The shell fragments were recovered from anthropogenic sediments using a $1.4 \mathrm{~mm}$ geological sieve as part of the heavy fraction recovery portion of archaeobotanical studies. A summary of the recovered remains and the density of shell fragments in the sediments are presented in Table 1. The data used in this study come from 12 archaeological sites, broadly speaking, 11 of which are urban or village sites and have been associated with agropastoral communities. One additional site, LVD-HA-K7 (in the Bukhara Oasis), is a burial mound and was linked to a different population of people than those living in the urban sites. Interestingly, palaeoproteomics analysis of the eggshells from the burial mound suggest that they were not from chickens; all other tested eggshells were identified as chicken. Two archaeological sites date to the Hellenistic period, Bash Tepa and Paykend 1; both of which had eggshells in their sediments in relatively high densities, which were recovered from more than 50 percent of the sampled contexts. In Samanid and Qarakhanid period sediments, we recovered eggshells at even higher densities, being prominent in samples from Kafir Kala, Bukhara, Afrasiab, Panjakent 2, and

Paykend 2 and 3 . Collectively, these data suggest continual and regular deposition of eggshells across all sites and throughout the sediment accumulation period. 


\begin{tabular}{|c|c|c|c|c|c|c|}
\hline Site & $\begin{array}{l}\text { Number } \\
\text { of } \\
\text { Samples }\end{array}$ & $\begin{array}{l}\text { Age of } \\
\text { Samples }\end{array}$ & $\begin{array}{l}\text { Liters of } \\
\text { Sediment }\end{array}$ & $\begin{array}{l}\text { Number of } \\
\text { eggshell } \\
\text { fragments }\end{array}$ & $\begin{array}{l}\text { Ubiquity } \\
\text { (samples with } \\
\text { eggshells) }\end{array}$ & $\begin{array}{l}\text { Density } \\
\text { (eggshells } \\
\text { per liter) }\end{array}$ \\
\hline Bash Tepa & 30 & $200-1 \mathrm{BC}$ & 764 & 460 & $0.7(70 \%)$ & 0.602 \\
\hline $\begin{array}{l}\text { Paykend } 1 \\
\text { (Citadel) }\end{array}$ & 10 & $\begin{array}{l}\text { 3rd century } \\
\text { BC-5th century } \\
\text { AD }\end{array}$ & 350.5 & 20 & $0.3(30 \%)$ & 0.057 \\
\hline $\begin{array}{l}\text { Panjakent } \\
\text { (Kainar- } \\
\text { citadel) }\end{array}$ & 9 & $\begin{array}{l}\text { 5-7th centuries } \\
\mathrm{AD}\end{array}$ & 116.5 & 25 & $0.88(88 \%)$ & 0.215 \\
\hline $\begin{array}{l}\text { Panjiakent } \\
\text { (Main town) }\end{array}$ & 11 & $\begin{array}{l}\text { 7-8th centuries } \\
\mathrm{AD}\end{array}$ & 264.5 & 56 & $0.64(64 \%)$ & 0.211 \\
\hline Sanjar-Shah & 5 & $\begin{array}{l}\text { 8-9th centuries } \\
\mathrm{AD}\end{array}$ & 65.5 & 26 & $0.8(80 \%)$ & 0.397 \\
\hline Kuk-Tosh & 6 & $\begin{array}{l}\text { 9-12th } \\
\text { centuries AD }\end{array}$ & 79 & 2,847 & $0.83(83 \%)$ & 36.038 \\
\hline Bukhara & 26 & $\begin{array}{l}\text { 9-12th } \\
\text { centuries AD }\end{array}$ & 939.5 & 871 & $0.46(46 \%)$ & 0.927 \\
\hline Tashbulak & 22 & $\begin{array}{l}10-12 \text { th } \\
\text { centuries AD }\end{array}$ & 223.5 & 95 & $0.23(23 \%)$ & 0.425 \\
\hline Afrasiab & 1 & $\begin{array}{l}10-12 \text { th } \\
\text { centuries } \mathrm{AD}\end{array}$ & 255 & 855 & $1(100 \%)$ & 3.352 \\
\hline $\begin{array}{l}\text { Paykend } 2 \\
\text { (Shakhristan) }\end{array}$ & 2 & $\begin{array}{l}10-12 \text { th } \\
\text { centuries } \mathrm{AD}\end{array}$ & 55 & 101 & $0.5(50 \%)$ & 1.836 \\
\hline $\begin{array}{l}\text { Paykend } 3 \text { - } \\
\text { (Rabat4) }\end{array}$ & 20 & $\begin{array}{l}\text { 10-12th } \\
\text { centuries AD }\end{array}$ & 357.5 & 90 & $0.5(50 \%)$ & 0.251 \\
\hline
\end{tabular}

* Paykend 1 and 2 represent the Citadel and Shakhristan II areas excavated during 2019; while Paykend 3 represents the neighboring medieval caravansary (Rabat-4). Samples from Kafir Kala and LVD-HA-K7 were handpicked and therefore not included in this table.

Table 1. Eggshell densities and ubiquities by site and date.

\section{Peptide Mass Fingerprinting}

Peptide mass fingerprints were obtained for eggshell fragments from four archaeological sites, Afrasiab $(n=5)$, Paykend $(n=5)$, Bash Tepa $(n=5)$, Tashbulak $(n=1)$, and burial mound LVD-HA-K7 $(n=2)$ (see Extended Data Table 2 for a detailed overview of the sample numbers, context information and identification). The majority of the samples (16 out of 18 ) were identified as chicken (Figure 4). The identification to G. gallus was confirmed with LC-MS/MS data to rule out a possible origin to a genetically closely related genus in the Galliformes family, such as pheasant (see Supplementary Table 1 and Extended Data Table 3). All of the chicken samples were from residential contexts. The only two samples not identified as chicken were from a non-residential context, burial mound LVD-HA-K7. One sample was identified as Anseriformes, based on earlier published markers ${ }^{19}$. The other has a low-quality spectrum more consistent with Anseriformes than chicken, but there were too few peaks present for confident taxonomic identification. Within Anseriformes, it is not possible to identify either sample to a more precise taxonomic level, since the majority of the MALDI peptide markers published are identical in all studied species from this order ${ }^{20}$. 


\section{Discussion}

\section{Evidence for Non-Seasonal Egg Laying}

We argue that the data in this manuscript provide strong evidence, not only for the rearing of chickens for eggs, but also for a prominence in egg production across a significant portion of the year. We present evidence for ancient chicken eggshells from 12 different archaeological settings, spanning a period of a millennium and a half. More informatively, eggshells were recovered at high ubiquity from these sites, meaning they were located in most of the stratigraphic layers and archaeological contexts that we examined. It is well-established by archaeobotanists that artefacts recovered in many different archaeological contexts are more likely to represent frequent-occurrence events, as opposed to seasonal or semi-annual events ${ }^{21-24}$. In archaeobotany, this reasoning is often applied to grain chaff, suggesting that high ubiquity of remains likely represents a situation where a household processes grain daily and stores the crop in its chaff, as opposed to one seasonal grain threshing event and the storage of grain in a cleaned state. The same reasoning applies to the eggshells in these assemblages - their abundance and ubiquity, not only illustrate their importance in the dietary economy, but also their regular use as a daily or common food over much of the season. The wild reproductive cycle of a chicken progenitor consists of one brood of eggs a year, with a clutch of less than 6 eggs $^{7}$. We suggest that, our identification of eggshells is evidence that these chickens had lost their habits of reproduction from the wild and were producing eggs at a regular rate for a significant part of the year.

While few archaeological projects have specifically sought out eggshell fragments in anthropogenic sediments, they are occasionally reported. However, evidence from before the first century BC for chicken eggs is completely lacking. Eggshell fragments were reported from Roman Mons Claudianus in Egypt, and Van Neer et al. ${ }^{25}$ argued that the prominence of medullary bones at the Roman site of Berenike is indicative of an egg-focused chicken industry. Evidence for egg production in Roman Britain comes from tablets found at Hadrian's Wall, noting receipt of, among other items one or two hundred eggs (chickens are among the other listed items ${ }^{26}$ ). More informatively, eggshells have been identified at 38 Roman period sites in Britain ${ }^{27}$; using a combination of SEM and peptide mass fingerprinting identification techniques, the eggshells from the amphitheater at Chester, Cheshire (AD 70-80), were identified as chicken ${ }^{26}$. Further evidence for egg production in the Roman period comes from Diodorus of Siculus, who mentioned a way to incubate chicken eggs. Columella ${ }^{18}$ (Book VIII: II:3-8) discussed specialized chicken farmers and suggested that certain kinds of chickens were better for cockfighting and others for egg laying. Some of the breeds he mentions appear to have originated on islands, and may have already diverged through insularity over the previous few centuries. He specifically references a form of poultry from Adria, near modern-day Venice; the Adrian chicken is also noted by Pliny the Elder ${ }^{9}$. Aristotle's ${ }^{28}$ famous chicken embryo evo-devo studies may further attest to the prominence of eggs in ancient Greece. Eggs are mentioned in Apicius' Cook Book ${ }^{29}$ (Book 6, chapter 248:2-3). Pliny claimed that the best birds could lay daily, but most historians agree that this is a significant exaggeration, as were many of Pliny's 
claims $^{30}$. Additionally, Varro ${ }^{31}$ (Book III, 481) discusses how to care for hens when they are laying and further illustrated the prominence of chicken egg production by the early Roman period.

As a final line of evidence for a deeper legacy of egg-laying chickens in West Asia, historical landraces or ecotypes attest to a long legacy (stretching back at least for several centuries) of egg-laying chickens. Genetic studies suggest that there has been long-term isolation and maintenance of insular breeds in remote areas of Iran and Turkey ${ }^{32,33}$. This deep continuity of egg-laying breeds may suggest that the traits of many reproductive cycles within a season evolved before the dispersal of chickens into Europe. That said, the rapid and ongoing extinction of ancient landraces in southwest Asia is evidence that recently developed (within the last century) breeds are far more productive than the ancient ones ${ }^{32}$. In fact, modern commercial poultry production has largely erased the genetic legacy of ancient chicken landraces or ecotypes globally, further complicating studies of the origins and dispersal of this enigmatic animal $^{34}$.

\section{The Rise in Symbolic and Economic Prominence of the Chicken in Central Asia}

Specialization in chicken farming and the focus on breeds and large-scale egg laying, as described by Columella, did not continue in Europe after the Roman period and was not resurrected until the early nineteenth century ${ }^{9}$. In medieval Europe the chicken took on the role of a barn-yard scavenger and may have been of some economic importance to members of lower socioeconomic status; during the early nineteenth century, the prominence of chickens in Europe again rose and specialized poultry farms developed. The situation in Central and southwest Asia appear to be different - we report the presence of chicken eggs in high ubiquity, density, and abundance at all sites that we studied for this paper through the medieval period. The rooster is extremely prominent in Zoroastrian imagery; although, so are mythical birds, such as the Sogdian hybrid bird priests and phoenix with ribbons. Zoroastrian texts make reference to the cock as the Herald of the Dawn ${ }^{35}$ or the Guardian of Good against Evil ${ }^{36}$. Also, while not necessarily a chicken egg, the world-egg myth is a prominent feature in Zoroastrian belief, as with other Proto-Indo-European traditions ${ }^{37}$.

One of the earliest and most vivid examples of this imagery in Central Asia was recovered in 2014 by the Karakalpak-Australian Expedition in the form of a wall paintings in the royal contexts of Akchakhan-kala, depicting a characteristic motif of two opposing human-headed roosters in the middle of performing a Zoroastrian ritual (first century $B C$ - first century $A D^{38}$ ). The image is the earliest representation of figures from the Avestan pantheon, and has led some scholars to suggest stronger Central Asian roots in the origins of the rooster-worshiping cult ${ }^{4,38}$. The hybrid bird-priest motif represents an assistant of Sraosha and is said to be a rooster that can predict the coming of dawn, waking up the religious practitioners to fulfil their duties (Vendīdād XVIII, 14-15 and 22-236). Rooster priest are prominent on Sogdian funerary couches, such as the depiction of two Zoroastrian rooster priests at a fire temple from the Shelby White and Leon Levy Collection at the Met $\left(6^{\text {th }} \text { century } A D\right)^{5}$. There are also two rooster priests depicted in relief on Lord Shi's sarcophagus, each with clear leg spurs (AD 579; Figure 2h). On a similar sarcophagus, Yu 
Hong's (AD 592), also from Xinjiang, the tails are clearly "cock-like"39). Two rooster priests also flank a fire on An Jia's tympanum above the doorway to the funerary chamber ${ }^{39}$. Ancient Chinese depictions of funerary birds, identified as phoenixes or vermilion birds, invariably have clear features that link them in style to pheasants, whereas Central Asian funerary birds have up-turned tails and leg spurs like roosters. The clear representations of leg spurs on most of the rooster priest chimeras, verifies that they are Galliformes. In Aramaic document C-1 (line 13) from ancient Bactria, dated to the month of Kislev of the $1^{\text {st }}$ year of Artaxerxes V (the usurper Bessus, November - December $330 \mathrm{BC}$ ), among the supplies provided to Bessus as he passed from Bactra (modern Balkh) eastward to Varnu, were 30 chickens (in addition to five geese, 33 lambs, 133 sheep, one donkey, four bovines, one calf, one horse, as well as oil, wine, flour, etc ${ }^{40}$ ).

The earliest report for chickens in Central Asia currently comes from bones recovered at the site of Kyzyl Tepa, dating between the sixth and fourth centuries BC in the Syrkhandarya region of Uzbekistan ${ }^{41}$. Identifications of the Kyzyl Tepa zooarchaeological remains were conducted separately by Pam Crabtree and Norbert Benecke, both of whom identified chicken bones in the assemblage. However, they represent the lowest abundance of any domesticated food animal (NISP $=12$ out of 2,900) and are not even presented in the summary table for domesticated animals in the study. Notably, wild goose bones are more abundant in the assemblage than chickens ${ }^{41}$. Other evidence for early chickens comes from a coin produced around $300 \mathrm{BC}$ depicting the Satrap of Bactria, Sophytes, which is an Indian name - possibly suggesting links to the south (Figure 2c). The coin was minted in a Greek style, depicting a rooster on one side. Faunal studies from the 2012 excavations at the site of Ulug-Depe in Turkmenistan resulted in the identification of chicken remains from the last phase of occupation at the site (Pre-Achaemenid and Achaemenid (Yaz II) 1100-329 BC ${ }^{42}$ ). While these remains have not yet been directly dated, it is informative to point out that they are absent from all earlier layers at the site. Wooden slab documents recovered from a military guard tower or postal station near the Silk Road town of Dunhuang, dating to $62 \mathrm{BC}$ mention the import and export of chickens ${ }^{43}$. Also discovered in Xinjiang, faunal remains from Yuansha Gucheng have been reported to contain chicken bones dating to the third or fourth centuries $A D^{44}$.

Chicken bones have also been reported at the medieval Islamic capital of Shahr-e Gholgholah, located at 2,600masl in the Bâmiyân Valley of Afghanistan ${ }^{45}$. Two roosters were also depicted flanking a fire alter in Temple B in Surkh-Kotal, Afghanistan, dating to the second century $A D^{39}$. Two half-bird creatures were also said to have once flanked an image of Mithras on the two Buddhas of Bamiyan ${ }^{46}$. Further south, at the Iranian site of Dasht Qal'eh, chicken bones have been reported from layers dating to the fifth or sixth centuries AD, but other large (non-chicken) bird bones were also recovered, identified as pheasants, waterfowl, and raptors ${ }^{47}$. Lerner ${ }^{48}$ compiled Sasanian $\left(7^{\text {th }}-8^{\text {th }}\right.$ centuries AD) stamp seals with rooster depictions, which she argues had apotropaic functions. One of the key cookbooks that has survived from the Golden Age of Islam, which was originally compiled in Syria for the Ayyubid rulers, is the Kitab alWuslah ila I-Habib fi Wasf al-Tayyibat wal-Tib (Scents and Flavors the Banqueter Favors). This book 
contains 635 recipes and medicinal concepts, such as presenting ways to balance the humors, and idea popular from Europe to East Asia by this time ${ }^{49}$. Eggs merit a special section in this book, which contains thirty-eight types of egg-based dishes. Chickens and eggs remain prominent in Central Asian imagery through the medieval period, one example is provided in Figure 2, with a fired clay egg on display at the Arc Museum in Bukhara, dated to sometime between the $10^{\text {th }}$ to $12^{\text {th }}$ centuries AD.

Linguistic evidence also suggests recent links between the bird, as it spread across West Asia. The common Iranian word for "chicken" is *krøka- (Avestan kahrka-, Middle Persian kark, Ossetic kark, Wakhi $k \ni r k$, etc), which is explained as phonosemantic formation meaning "cackling one", the similar IndoEuropean formation sometimes means chicken too (Tocharian krankko, Greek kérkos, old Slavic kurb for rooster), and sometimes other birds (Old Indian $k r \Downarrow k a \bar{r} a$ for partridge ${ }^{50}$ ). The word for rooster such as Persian xurōs is derived from another root meaning to cry. In many modern languages the hen retaines the meaning of "bird" in general, e.g. Tajik mury or Uzbek paranda. The word for "chicken" (Sogdian $c w z^{\prime} k k$, Persian jujeh, etc) is again onomatopoetic.

\section{Conclusions}

Chickens and chicken eggs have been an important aspect of Central Asian culture and economy for more than two millennia. Beyond a source of food, archaeological evidence has firmly established that the chicken, specifically the rooster, has long been a symbol of virility in Inner Asia, and, to the Zoroastrian faith, the rooster represents a spirit that calls at dawn to praise the triumph of light over dark in the eternal struggle between night and day. This domesticated bird's importance at the heart of the Silk Road may have facilitated its rapid dispersal across two and a half continents by roughly two millennia ago. In this manuscript, we present evidence for regular consumption of chicken eggs at many of the largest urban centers of medieval Central Asia, including Afrasiab, Paykend, Panjikent, and Bukhara. We also discuss new finds from the ancient mountain village of Tashbulak and the Hellenistic fortified sites of Paykend and Bash Tepa. The earliest clear evidence for non-seasonal egg laying dates to the Hellenistic period, at which time the more productive birds were already present across Central Asia and the eastern Mediterranean. By the Roman period, specialized poultry farms existed in southern Europe and northern Africa. However, the role of the chicken in Medieval Europe switched to that of a farm-yard scavenger; whereas across Central and southwest Asia, during the Golden Age of Islam, chicken egg production appears to have remained important and continued on a large scale in cities and villages. Chickens express an impress reaction norm of developmental plasticity and are therefore easy to spread into different climates and environmental zones. The eggshell fragments from these sites at the center of the ancient trans-Eurasian trade routes illustrate: 1 ) that chicken eggs were a regular part of the diet starting in the last centuries BC; and 2) the chicken and the egg remained important in urban centers across Central Asia until at least the Qarakhanid period. Given the difficulties in morphologically identifying chicken bones, the highly fragmentary state they are usually preserved in, and their paucity in early contexts, peptide mass fingerprinting is well suited to clarify the domestication and dispersal narrative for 
the most enigmatic of the Old World domesticated animals (see Supplementary Discussions 1 and 2 for a summary of the ongoing debates and lack of clarity).

\section{References}

1 Perry-Gal, L., Erlich, A., Gilboa, A. \& Bar-Oz, G. Earliest economic exploitation of chicken outside East Asia: Evidence from the Hellenistic Southern Levant. PNAS 112, 9849-9854, doi:10.1073/pnas.1504236112 (2015).

2 Redding, R. W. The Pig and the Chicken in the Middle East: Modeling Human Subsistence Behavior in the Archaeological Record Using Historical and Animal Husbandry Data. J. Archaeol. Res. 23, 325-368, doi:10.1007/s10814-015-9083-2 (2015).

3 von der Osten-Sacken, E. Untersuchungen zur Geflügelwirtschaft im Alten Orient (Academic Press/Vandenhoeck \& Ruprecht, Fribourg/Göttingen, 2015).

$4 \quad$ Betts, A. et al. Des divinités avestiques sur les peintures murales d'Akchakhan-kala, Ouzbékistan. CRA/159, 1369-1396 (2015).

5 Wertmann, P. Sogdians in China: Archaeological and Art Historical Analyses of Tombs and Texts from the 3rd to the 10th Century AD (Darmstadt, Verlag Philipp von Zabern, 2015).

6 Grenet, F. \& Minardi, M. The Image of the Zoroastrian God Srōsh: New Elements. Anc. Civiliz. Scythia Sib. 27, 154-173, doi:10.1163/15700577-12341389 (2021).

$7 \quad$ Lawler, A. Why did the Chicken Cross the World? (Atria, New York, 2014).

8 Sauer, C. O. Agricultural origins and dispersals (The American Geographical Society, 1952).

9 Wood-Gush, D. G. M. A History of the Domestic Chicken from Antiquity to the 19th Century. Poult. 38, 321-326, doi:10.3382/ps.0380321 (1959).

10 Carter, G. F. in Man Across the Sea: Problems of pre-Columbian contacts (eds C.L. Riley, J.C. Kelley, C.W. Pennington, \& R.L. Rands) 78-218 (University of Texas Press, Austin, 1971).

11 von den Driesch, A. \& Pöllath, N. in Vorträge des 18. Niederbayerischen Archäologentages (ed K. Schmotz) 145-162 (Marie Leidorf, Rahden, Westfalen, 2000).

12 Cicero, M. T. Cicero: On Divination, Book 1 (Oxford University Press, Oxford, 2007 [44BC]).

13 West, B. \& Zhou, B.-X. Did chickens go North? New evidence for domestication. J. Archaeol. Sci. 15, 515-533, doi:10.1016/0305-4403(88)90080-5 (1988).

14 Hodgson, N. in Excavations at South Shields Roman Fort Vol. 1 (eds P. Bidwell \& S. Speak) (Society of Antiquaries of Newcastle upon Tyne, Newcastle upon Tyne, 1994). 
15 Zeuner, F. E. A History of Domesticated Animals (Harper and Row, New York, 1963).

16 Woldekiros, H. S. et al. Archaeological and biometric perspectives on the development of chicken landraces in the Horn of Africa. Int. J. Osteoarchaeol. 29, 728-735, doi:10.1002/oa.2773 (2019).

17 Eyre, L. B. Nordeskiold: The history of biology (Tudor Publishing, New York City, 1946).

18 Forster, E. S. \& Heffer, E. H. Columella: De Re Rustica (William Heinemann, London, 1941).

19 Presslee, S. et al. The identification of archaeological eggshell using peptide markers. Sci. Technol. Archaeol. Res. 3, 89-99, doi:10.1080/20548923.1424300 (2017).

20 Demarchi, B., Presslee, S., Sakalauskaite, J., Fischer, R. \& Best, J. The role of birds at Çatalhöyük revealed by the analysis of eggshell. Quat. Int. 543, 50-60, doi:10.1016/j.quaint.2020.02.009 (2020).

21 Fuller, D. Q. \& Stevens, C. J. in From Foragers to Farmers. Papers in Honour of Gordon C. Hillman (eds Andrew S. Fairbairn \& Ehud Weiss) 37-57 (Oxbow Books, Oxford, 2009).

22 Fuller, D. Q., Stevens, C. J. \& McClatchie, M. in Ancient Plants and People. Contemporary Trends in Archaeobotany (eds M. Madella, C. Lancellotti, \& M. Savard) 174-217 (University of Arizona Press, Tucson, 2014).

23 Stevens, C. J. An Investigation of Agricultural Consumption and Production Models for Prehistoric and Roman Britain. Environ. Archaeol. 8, 61-76, doi:10.1179/env.2003.8.1.61 (2003).

24 Stevens, C. J. in The origin and spread of domestic plants in Southwest Asia and Europe (eds S. Colledge \& J. Conolly) 375-389 (Left Coast Press, Walnut Creek, 2007).

25 Van Neer, W., Noyen, K., De Cupere, B. \& Beuls, I. On the Use of Endosteal Layers and Medullary Bone from Domestic Fowl in Archaeozoological Studies. J. Archaeol. Sci. 29, 123-134, doi:10.1006/jasc.2001.0696 (2002).

26 Maltby, M., Allen, M., Best, J., Fothergill, B. T. \& Demarchi, B. Counting Roman chickens: Multidisciplinary approaches to human-chicken interactions in Roman Britain. J. Archaeol. Sci. Rep. 19, 1003-1015, doi:10.1016/j.jasrep.2017.09.013 (2018).

27 Allen, M. \& Smith, A. in New Visions of the Countryside of Roman Britain, Vol. 1: The Rural Settlement of Roman Britain. Britannia Monograph Series (eds A. Smith, M. Allen, T. Brindle, \& M. Fulford) 17-43 (Society for the Promotion of Roman Studies, London, 2016).

28 Aristotle. The works of Aristotle, Vol. 4 (Clarendon Press, Oxford, 1910 [fourth century BC]).

29 Apicius. De Re Coquinaria (1936).

30 Elder, P. t. Natural History (Harvard University Press, Cambridge, 1938 [AD79]). 
Varro, M. T. De Re Rustica (Loeb Classical Library, London, 1934 [37BC]).

32 Meydan, H., Jang, C. P., Yıldız, M. A. \& Weigend, S. Maternal Origin of Turkish and Iranian Native Chickens Inferred from Mitochondrial DNA D-loop Sequences. Asian-Australas. J. Anim. Sci. 29, 15471554, doi:10.5713/ajas.15.1060 (2016).

33 Shahbazi, S., Mirhosseini, S. Z. \& Romanov, M. N. Genetic Diversity in Five Iranian Native Chicken Populations Estimated by Microsatellite Markers. Biochem. Genet. 45, 63-75, doi:10.1007/s10528-0069058-6 (2007).

34 Storey, A. A. et al. Investigating the Global Dispersal of Chickens in Prehistory Using Ancient Mitochondrial DNA Signatures. PLOS ONE 7, e39171, doi:10.1371/journal.pone.0039171 (2012).

35 Dhalla, M. N. Zoroastrian Civilization (Oxford University Press, Oxford, 1922).

36 Crawford, R. D. in Poultry Production (ed P. Hunton) 1-20 (Elsevier, Amsterdam, 1995).

37 Williams, A. in Papers in Honour of Professor Mary Boyce (ed J. Duchesne-Guillemin) 683-697 (E.J. Brill, Leiden, 1985).

38 Betts, A. et al. The Akchakhan-kala Wall Paintings: New Perspectives on Kingship and Religion in Ancient Chorasmia. J. Inner Asian Art Archaeol. 7, 125-165, doi:10.1484/j.Jiaaa.4.2017007 (2016).

39 Riboud, P. Bird-Priests in Central Asian Tombs of 6th-Century China and Their Significance in the Funerary Realm. Bull. Asia Inst. 21, 1-23 (2007).

40 Naveh, J. \& Shaked, S. Aramaic Documents from Ancient Bactria (Fourth Century BCE) from the Khalili Collections (Khalili Family Trust, London, 2012).

41 Wu, X., Miller, N. F. \& Crabtree, P. Agro-Pastoral Strategies and Food Production on the Achaemenid Frontier in Central Asia: A Case Study of Kyrzyltepa in Southern Uzbekistan. Iran 53, 93-117, doi:10.1080/05786967.2015.11834752 (2017).

42 Bendezu-Sarmiento, J. Ulug Depe. A forgotten city in Central Asia (MAFTUR. Mission Archéologique Franco-Turkmene, MAE, CNRS, 2012).

43 Sterckx, R. Food, Sacrifice, and Sagehood in Early China (Cambridge University Press, Cambridge, 2011).

44 Debaine-Francfort, C., Debaine, F. \& Idriss, A. in Water and Sustainability in Arid Regions: Bridging the Gap Between Physical and Social Sciences (eds Graciela Schneier-Madanes \& Marie-Francoise Courel) 181-202 (Springer Netherlands, Dordrecht, 2010).

45 Monchot, H., Lorain, T. \& Bendezu-Sarmiento, J. in Humans and Caprines. From mountain to steppe, from hunting to husbandry (eds L. Gourichon, C. Daujeard, \& J.-P. Brugal) 285-297 (Éditions 
APDCA, Antibes, 2019).

46 Grenet, F. Mithras, dieu Iranien: Nouvelles données. Topoi 11, 35-38 (2003).

47 Mashkour, M., Radin, V. \& Thomas, R. in Persia's Imperial Power in Late Antiquity: The Great Wall of Gorgon and Frontier Landscapes of Sasanian Iran (ed E.W. Sauer) 539-672 (Oxbow Books, Oxford, 2013).

48 Lerner, J. A note on Sussanian harpies. Iran 13, 166-171 (1975).

49 Perry, C. Scents and Flavors the Banqueter Favors (Kitab al-Wuslah ila I-Habib fi al-Tayyibat walTib) (New York University Press, New York, 2017 [thirteenth century]).

50 Edel'man, D. I. Etymology Dictionary of Iranian Languages (in Russian), Vol. 4 (Vostochnaja literatura, Moscow, 2011).

\section{Methods}

Sampling and Morphological Identification

For most of the sites discussed in this text, systematic collection of sediment samples for archaeobotanical floatation was conducted. The heavy fraction of the samples was wet screened though a $1.4 \mathrm{~mm}$ geological sieve. The eggshells were collected from the wet screened sediments and recorded as to how many fragments per liter of sediment were recovered. For the site of Kafir Kala, eggshell fragments were handpicked by excavators during excavation, and further sediment samples have been collected but remains unfloated at present. The samples were fit into contexts using both radiocarbon dating and stratigraphic sequencing. All of the case studies in this paper are part of larger excavations and ongoing projects. The identification of eggshells was further conducted using a scanning electron microscope, which allowed us to verify that the breathing pores on the eggs matched those of modern chicken eggs in morphology and size. A selection of the shell fragments was then sent to the ZooMS facilities at the Max Planck Institute for the Science of Human History for further identification certainty.

\section{Peptide Mass Fingerprinting}

Eggshell fragments were analyzed alongside a blank based upon previously published methods ${ }^{19,51}$. Eggshell fragments of approximately $20 \mathrm{mg}$ were cleaned with $400 \mu \mathrm{l} 0.5 \mathrm{M}$ EDTA, washed three times with $400 \mu \mathrm{l}$ ultra-pure water and left to dry overnight. Fragments were then crushed into a powder and incubated in $200 \mu \mathrm{l} \mathrm{NaOCL}(12 \% \mathrm{w} / \mathrm{v})$ for 5 days. The supernatant was discarded and the samples were rinsed five times with $200 \mu \mathrm{l}$ ultra-pure water, then they were resuspended in methanol (100\%) and left to dry overnight. Samples were demineralized in $500 \mu \mathrm{l} 0.6 \mathrm{M}$ hydrochloric acid $(\mathrm{HCl})$ for $10 \mathrm{~min}$ after which $500 \mu \mathrm{l}$ of the supernatant was transferred to a $10 \mathrm{kDa}$ ultrafilter (Sartorius, Vivaspin ${ }^{\circledR}$ ) and centrifuged until completely passed through the filter. $500 \mu \mathrm{l}$ of $50 \mathrm{mM}$ ammonium bicarbonate (AmBic) was then added to the ultrafilter and the samples were centrifuged a second time. The filtrates were resuspended in 
$200 \mu \mathrm{l}$ AmBic. Half of the supernatant was transferred to a second tube, which was stored as a back-up. $11 \mu \mathrm{l}$ of $100 \mathrm{mM}$ CAA (2-chloracetamide)/100 mM TCEP (tris[2-carboxyethyl]phospine) solution was added to the remaining sample supernatant, and then they were digested with $1 \mu \mathrm{l} 0.4 \mu \mathrm{g} / \mu \mathrm{l}$ of trypsin solution (Pierce ${ }^{\mathrm{TM}}$ Trypsin Protease, Thermo Scientific) for $18 \mathrm{~h}$ at $37^{\circ} \mathrm{C}$. Following enzymatic digestion, peptides were purified and concentrated using $100 \mu \mathrm{l}$ C18 resin ZipTips (Pierce ${ }^{\mathrm{TM}} \mathrm{C} 18 \mathrm{Tips}$, Thermo Scientific) with conditioning and eluting solutions composed of $50 \%$ acetonitrile (v/v) and $0.1 \%$ TFA and a lower hydrophobicity wash buffer of $0.1 \%$ TFA. Peptides were eluted in $50 \mu$ conditioning solution.

The samples were spotted in triplicate onto an MTP AnchorChip 384-target plate, together with matrix solution (10 mg a-cyano-4-hydroxycinnamic in $7 \mathrm{~mL} \mathrm{85 \%}$ acetronitrile [ACN]/0.1\% trifluoracetic acid [TFA]). The samples were analysed using an Autoflex Speed LRF matrix-assisted laser desorption/ionization-tandem time of flight mass spectrometer (MALDI-TOF-MS, Bruker Daltonics) with a smartbeam-II laser. A SNAP averaging algorithm was used to obtain monoisotopic masses (C: $4.9384, \mathrm{~N}$ : $1.3577,0: 1.4773, \mathrm{~S}: 0.0417, \mathrm{H}: 7.7583)$. Resulting spectra were examined manually using the opensource software mMass ${ }^{52}$ using peak picking with a signal to noise ratio of 3.0. Observed peaks were matched to a list of published taxon-specific $m / z$ values ${ }^{19,53-55}$.

In order to confirm taxonomic identification, one eggshell sample with a high-quality MALDI spectra, identified as chicken (sample CP565, Afrasiab) was selected for further analysis using liquid chromatography with tandem mass spectrometry (LC-MS/MS) to obtain peptide sequence data. $20 \mu$ of the sample extract was dried down and sent for LC-MS/MS analysis at the Functional Genomics Center Zurich. LC-MS/MS was conducted using a Q-Exactive HF mass spectrometer (Thermo Scientific) coupled with an ACQUITY UPLC M-Class system (Waters AG). Solvent composition at the two channels was $0.1 \%$ formic acid for channel A and $0.1 \%$ formic acid, $99.9 \%$ ACN for channel B. Column temperature was 50 ${ }^{\circ} \mathrm{C}$. For each sample, $4 \mu \mathrm{l}$ of peptides were loaded on a commercial MZ Symmetry C18 Trap Column (100 $\AA, 5 \mu \mathrm{m}, 180 \mu \mathrm{m} \times 20 \mathrm{~mm}$, Waters) followed by nanoEase MZ C18 HSS T3 Column (100 ̊, $1.8 \mu \mathrm{m}, 75 \mu \mathrm{m}$ $\times 250 \mathrm{~mm}$, Waters). The peptides were eluted at a flow rate of $300 \mathrm{~nL} / \mathrm{min}$ by a gradient from 5 to $40 \% \mathrm{~B}$ in 120 min and $98 \%$ B in 5 min. The column was cleaned after each run with $98 \%$ solvent B for 5 min and holding $98 \%$ B for 8 min prior to re-establishing loading condition. The mass spectrometers were operated in data-dependent mode performing HCD (higher-energy collision dissociation) fragmentation on the 12 most intense signals per cycle. Full-scan MS spectra (300-1500 m/z) were acquired at a resolution of 120,000 at $200 \mathrm{~m} / \mathrm{z}$ after accumulation to a target value (AGC) of 3,000,000, while HCD spectra were acquired at a resolution of 30,000 using a normalized collision energy of 28 (maximum injection time: 50 ms; AGC 10,000 ions). Unassigned singly-charged ions and ions were excluded. Precursor masses previously selected for MS/MS measurement were excluded from further selection for $30 \mathrm{~s}$, and the exclusion window was set at $10 \mathrm{ppm}$. The samples were acquired using internal lock mass calibration on $\mathrm{m} / \mathrm{z} 371.1012$ and 445.1200 .

Byonic v.3.2.0 (Protein Metrics Inc. ${ }^{56}$ was used to analyse the LC-MS/MS data. The product ion spectra were searched against a reference database consisting of all sequence data in Swissprot and the entire proteomes of Anas plathyrhynchos plathyrhynchos (UP00001666), Aquila chrysaetos

Page 15/23 
chrysaetos (UP000472275), Bambusicola thoracicus (UP000237246), Corvus brachyrhynchos (UP000052976), Gallus gallus (UP000000539), Hailiaeetus albicilla (UP000054379), Numida meleagris (UP000243875), Opisthocomus hoazin (UP000053605) and Pterocles gutturalis (UP000053149), using the following parameter settings: fragment mass error: 30 ppm; precursor mass error: 5 ppm; cleavage sites semi-tryptic ragged $\mathrm{N}$-search; 2 missed cleavages allowed; mass changes: 2 common, 1 rare; fixed: carbamidomethyl on cysteine (C); common: oxidation on histidine $(H)$, methionine $(M)$, proline $(P)$ and tryptophan $(W)$, dioxidation on $M$ and $W$, trioxidation on $C$, deamidation on asparagine $(\mathrm{N})$ and glutamine $(\mathrm{Q})$, pyro-Glu on N-term Q; rare: ammonia-loss on N-term $\mathrm{C}$, pyro-Gly on $\mathrm{N}$-term glutamic acid (E); no sequence variations allowed, wildcard search disabled.

The masses of all observed MALDI $m / z$ peaks were compared to the list of peptides found in Byonic to identify corresponding peptide sequences (protein FDR $1 \%$, LogProb $\geq 1$, unique peptides $\geq 2$, and at least 2 peptides with a PEP2D score lower than 0.01). These sequences were aligned with published markers, checked for uniqueness using NCBI Blast and mapped back onto the corresponding protein sequences using Geneious Prime 2020.1.

\section{Methods references}

51 Van der Sluis, L. G. et al. Combining histology, stable isotope analysis and ZooMS collagen fingerprinting to investigate the taphonomic history and dietary behaviour of extinct giant tortoises from the Mare aux Songes deposit on Mauritius. Palaeogeog. Palaeoclimatol. Palaeoecol. 416, 80-91, doi:10.1016/j.palaeo.2014.06.003 (2014).

52 Strohalm, M., Hassman, M., Kosata, B. \& Kodícek, M. mMass data miner: an open source alternative for mass spectrometric data analysis. Rapid Commun. Mass Spectrom. 22, 905-908, doi:10.1002/rcm.3444 (2008).

53 Stewart, J. R. M. et al. Walking on Eggshells: A Study of Egg Use in Anglo-Scandinavian York Based on Eggshell Identification Using ZooMS. Int. J. Osteoarchaeol. 24, 247-255, doi:10.1002/oa.2362 (2013).

54 Stewart, J. R. M., Allen, R. B., Jones, A. K. G., Penkman, K. \& Collins, M. ZooMS: making eggshell visible in the archaeological record. J. Archaeol. Sci. 40, 1797-1804, doi:10.1016/j.jas.2012.11.007 (2013).

55 Demarchi, B. et al. Birds of prey and humans in prehistoric Europe: A view from El Mirón Cave, Cantabria (Spain). J. Archaeol. Sci. Rep. 24, 244-252, doi:10.1016/j.jasrep.2019.01.010 (2019).

56 Bern, M., Kil, Y. J. \& Becker, C. Byonic: Advanced Peptide and Protein Identification Software. Curr. Protoc. Bioinform. 40, 13.20.11-13.20.14, doi:10.1002/0471250953.bi1320s40 (2012).

57 Studer, J. in Archaeozoology of the Near East VVol. 62 (eds H. Buitenhuis, A.M. Choyke, M. Mashkour, \& A.H. Al-Shiyab) 273-281 (ARC Publicaties Groningen, 2002). 
58 Friedl, H. Tierknochenfunde aus Kassope/Griechenland (4.-1. Jh. v. Chr.). PhD thesis, Ludwich Maximilian University (1984).

59 Hoepfner, W., Dakaris, S., Gravani, K. \& Schwandler, E. L. in Geschichte des Wohnens, Band I: 5000 v. Chr.-500 n. Chr., Vorgeschichte, Frühgeschichte, Antike (ed W. Hoepfner) 368-383 (Deutsche VerlgsAnstalt, Stuttgart, 1999).

60 Dräger, N. Tierknochenfunde aus der Stadt auf dem Magdalensverg bei Klagenfurt in Kärnten, I. Die Vogelknochen, Vol. 33 (Verlas des Geschichtsvereines für Kärnten, Kärnten, 1964).

61 Moser, B. Die Tierknochenfunde aus dem latènezeitlichen Oppidum von Altenburg-Rheinau. I. Charakterisierung des Fundgutes, Pferd, Hund, Hausgeflügel und Wildtiere. PhD thesis, Ludwig Maximilian University (1986).

62 Boessneck, J. in Studien zu Abodiacum-Epfach (ed J. Werner) 213-261 (C.H. Beck, Munich, 1964).

63 Boessneck, J., von den Driesch, A., Meyer-Lemppenau, U. \& Wechsler-von Ohlen, E. Die Tierknochenfunde aus dem Oppidum von Manching (Franz Steiner Verlag, Frankfurt a.M., 1971).

64 Fuller, B. T. et al. Isotopic reconstruction of human diet and animal husbandry practices during the Classical-Hellenistic, imperial, and Byzantine periods at Sagalassos, Turkey. Am. J. Phys. Anthropol. 149, 157-171, doi:10.1002/ajpa.22100 (2012).

65 Sidebotham, S. E. \& Wendrich, W. Berenike 1997: Report of the 1997 Excavations at Berenike and the Survey of the Egyptian Eastern Desert, Including Excavations at Shenshef (Research School CNWS, Leiden, 1999).

66 Lentacker, A. \& Van Neer, W. Bird Remains from Two Sites on the Red Sea Coast and some Observations on Medullary Bone. Int. J. Osteoarchaeol. 6, 488-496, doi:10.1002/(SICl)10991212(199612)6:5<488::AID-OA301>3.0.C0;2-W (1996).

67 Hamilton-Dyer, S. The domestic fowl and other birds from the Roman site of Mons Claudianus, Egypt. Int. J. Osteoarchaeol. 7, 326-329, doi:10.1002/(SICI)1099-1212(199707/08)7:4<326::AIDOA358>3.0.CO;2-Y (1997).

68 Meadow, R. W. in Tepe Yahya: The Early Period (ed T.W. Beale) (Harvard University Press, Cambridge, 1986).

69 LaBianca, Ø. S., Haynes, L. A., Hubbard, L. E. \& Running, L. G. Sedentarization and Nomadization: Food System Cycles at Hesban and Vicinity in Transjordan (Andrews University Press, Berrien Springs, 1990).

70 Hellwing, S., Sade, M. \& Kishon, V. in Shiloh: The Archaeology of a Biblical Site. Monograph Series (ed I. Finkelstein) 309-350 (Institute of Archaeology, Tel Aviv University, Tel Aviv, 1993). 
71 Croft, P. in The Renewed Archaeological Excavations at Lachish (1973-1994) (ed D. Ussishkin) 2254-2348 (Emery and Claire Yass Publications in Archaeology, Tel Aviv, 2004).

72 Redding, R. W. in Excavations at Coptos (Qift) in Upper Egypt, 1987-1992. Supplemental Series (eds S.C. Herbert \& A. Berlin) 205-220 (Journal of Roman Archaeology, Portsmouth, 2003).

73 Boessneck, J., von den Driesch, A. \& Ziegler, R. in Maadi III: The Non-Lithic Finds and the Structural Remains of the Predynastic Settlement (eds I. Rizkana \& J. Seeher) 87-128 (Verlag Phillipp von Zabern, Mainz am Rhein, 1989).

74 Lepetz, S. L'animal dans l'économie gallo-romaine. Rev. Archeol. de Picardie 12, 81-147 (1996).

75 Davis, S. J. M. Mammal and Bird Remains from the Iron Age and Roman periods at Castro Marim, Algarve. Trabalhos de CIPA 107 (2007).

76 Hernandez-Carrasquilla, F. Some comments on the introduction of domestic fowl in Iberia. Archaeofauna 1, 45-53 (1992).

77 Trentacoste, A. The Etruscans and their Animals: the Zooarchaeology of Forcello di Bagnolo San Vito (Mantova). PhD thesis, University of Sheffield (2014).

78 De Grossi Mazzorin, J. in Atti del $3^{\circ}$ convegno nazionale di archeozoologica (eds I. Fiore, G. Malerba, \& S. Chilardi) 351-364 (Instituto Polografico e Zecca dello Stato, Rome, 2005).

79 Poulain-Josien, T. Un dépotoir augustéen à Argentomagus (Saint-Marcel, Indre). Rev. Archéol. Cent. Fr. 5, 3-39 (1966).

80 Seigle, M. Pules et coqs en Gaule durant les deux âges du Fer. Master thesis, Université Lumiere Lyon (2014).

81 Woldekiros, H. S. \& D'Andrea, A. C. Early Evidence for Domestic Chickens (Gallus gallus domesticus) in the Horn of Africa. Int. J. Osteoarchaeol. 27, 329-341, doi:10.1002/oa.2540 (2017).

\section{Declarations}

\section{Acknowledgements}

B. Demarchi provided proteomic reference data for chicken eggshell. Research funds and support were provided by the Max Planck Society and the European Research Council, grant number 851102 , Fruits of Eurasia: Domestication and Dispersal (FEDD).

\section{Author contributions}

C.P., K.K.R., N.B., and R.N.S. conceived and designed the study. C.P. and K.K.R. conducted proteomic analyses. B.M.M., M.V.B, K.A., and R.D.M. analyzed sediment samples and collected eggshell fragments. 
S.S., B.M.-M., F.M., M.S., R.H., A.B., M.F., T.H., F.K., A.O., S.W., P.L., and R.N.S. provided samples. C.P. and R.N.S. wrote the paper, with critical input from all authors.

\section{Competing interest declaration}

The authors declare no competing interests.

\section{Data availability statement}

MALDI-ToF-MS spectra that support the findings of this study are available in Zenodo (doi:

10.5281/zenodo.4084517). MS/MS data files are available at PXD031493 and were uploaded through MassIVE (MSV000088794, doi: 10.25345/C5HK35). For review, MS/MS data files are available for download with an FTP client using username 'MSV000088794_reviewer', password 'eggshell' and the download link: ftp://MSV000088794@massive.ucsd.edu. Upon acceptance the dataset will be made publicly available.

\section{Additional Information}

Supplementary Information is available for this paper. Correspondence and requests for materials should be addressed to Robert N. Spengler III (spengler@shh.mpg.de).

ORCID 0000-0002-5648-6930

\section{Extended data legends}

Extended Data Table 1: Key Archaeological Sites Supporting the Westward Spread, Linked to Figure 1.

Extended Data Table 2: Sample numbers, site and context information, and final identification of the eggshell fragments included in this study.

Extended Data Table 3: Proteins identified in sample CP565 (Afrasiab) with a LogProb $\geq 5$, and at least 2 unique peptides.

\section{Figures}




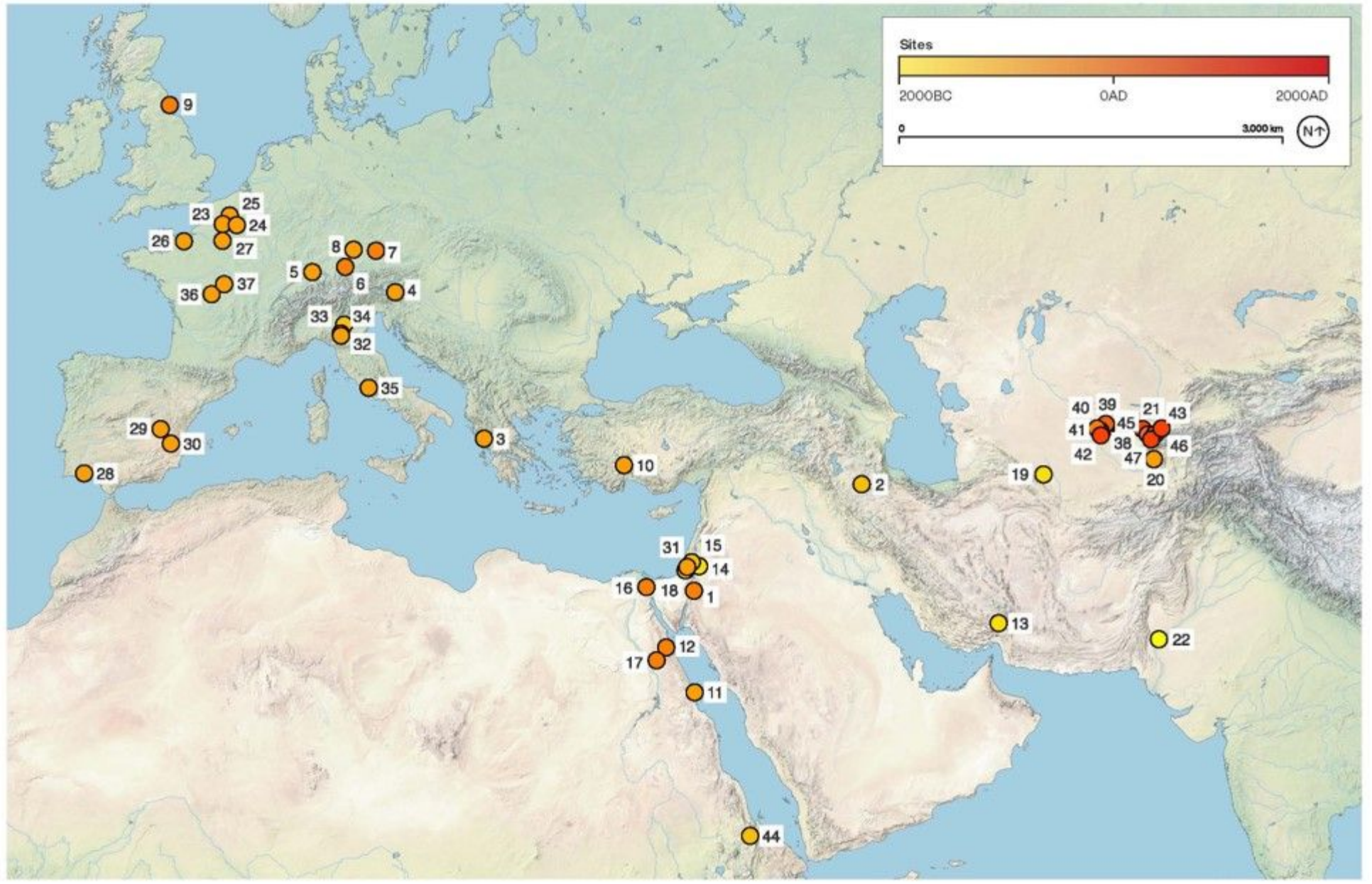

\section{Figure 1}

Key data points in the dispersal of the chicken, information for this map is provided in Extended Data Table 1 and Supplementary Discussion 3. Given the quantity of evidence for chickens in Roman and medieval Europe and West Asia, this map is not comprehensive, but rather provides an idea of the rapid rate of adoption of chicken rearing. 


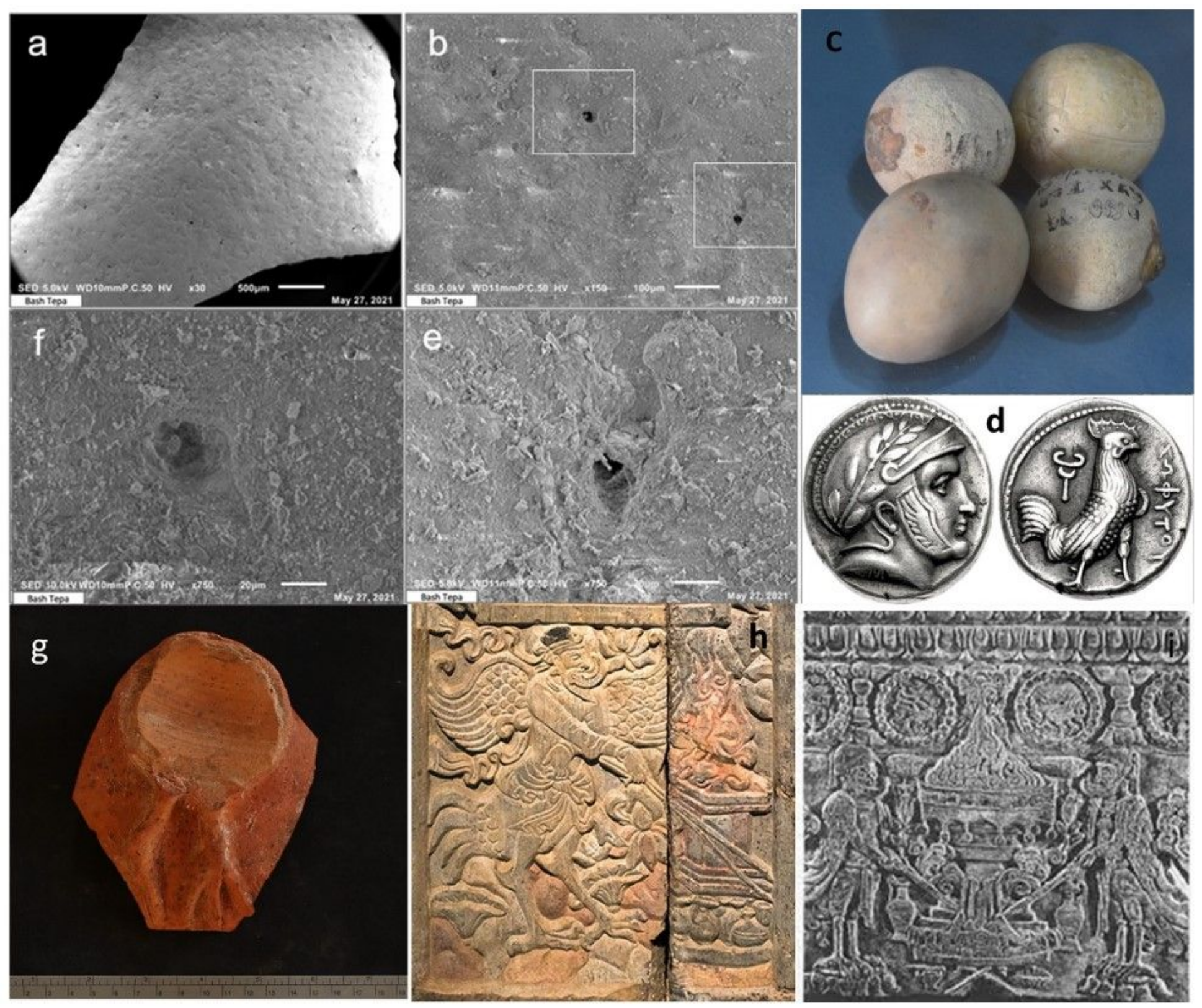

Figure 2

SEM images of a Bash Tepa egg shell, emphasizing morphologically distinct breathing pores at magnifications $x 30$ (a), x150 (b), x750 (e and f). c) a ceramic egg with clay balls from Bukhara dating between the tenth and twelfth centuries AD; d) the Sophytes coin from Bactria in $300 \mathrm{BC} ; \mathrm{g}$ ) a fragment of an ossuary from Bash Tepa dating to the last centuries BC, with an apparent chicken on the top; $h$ ) a depiction of a rooster priest on the sarcophagus of Lord Shi from the Xian Museum (AD 579); i) a sixth century depiction of two Zoroastrian rooster priests from the Met collections. 


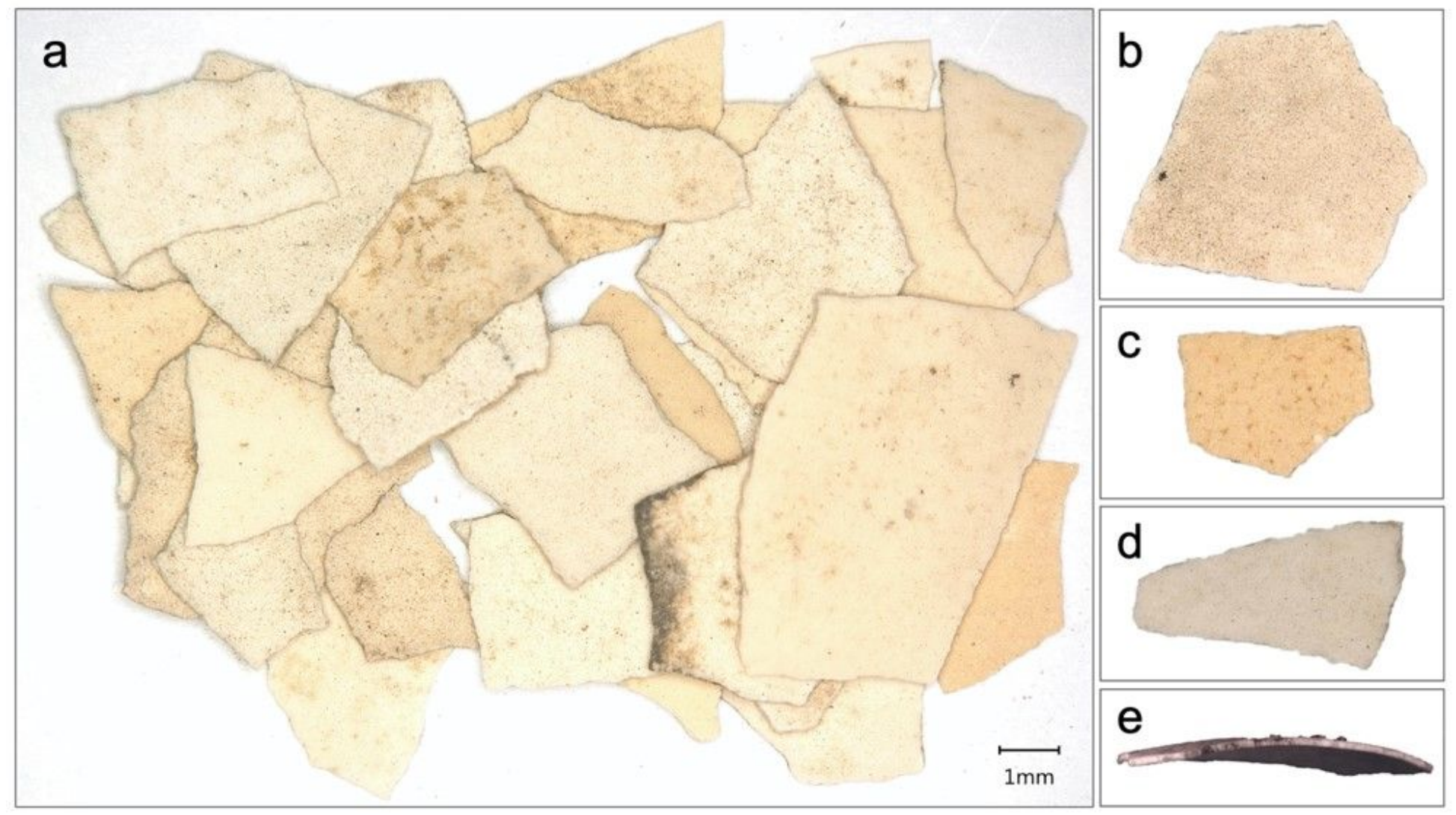

\section{Figure 3}

Image of fragments of ancient eggshells, showing the shape and surface coloration as well as the general curvature of the fragments. (a) eggshells from the Bash Tepa FS2 sample; (b) an eggshell from the Paykend FS8 sample (midden); (c) an eggshell from the Paykend FS15 sample (rabat); (d) an Afrasiab eggshell; and (e) a Tashbulak eggshell. 


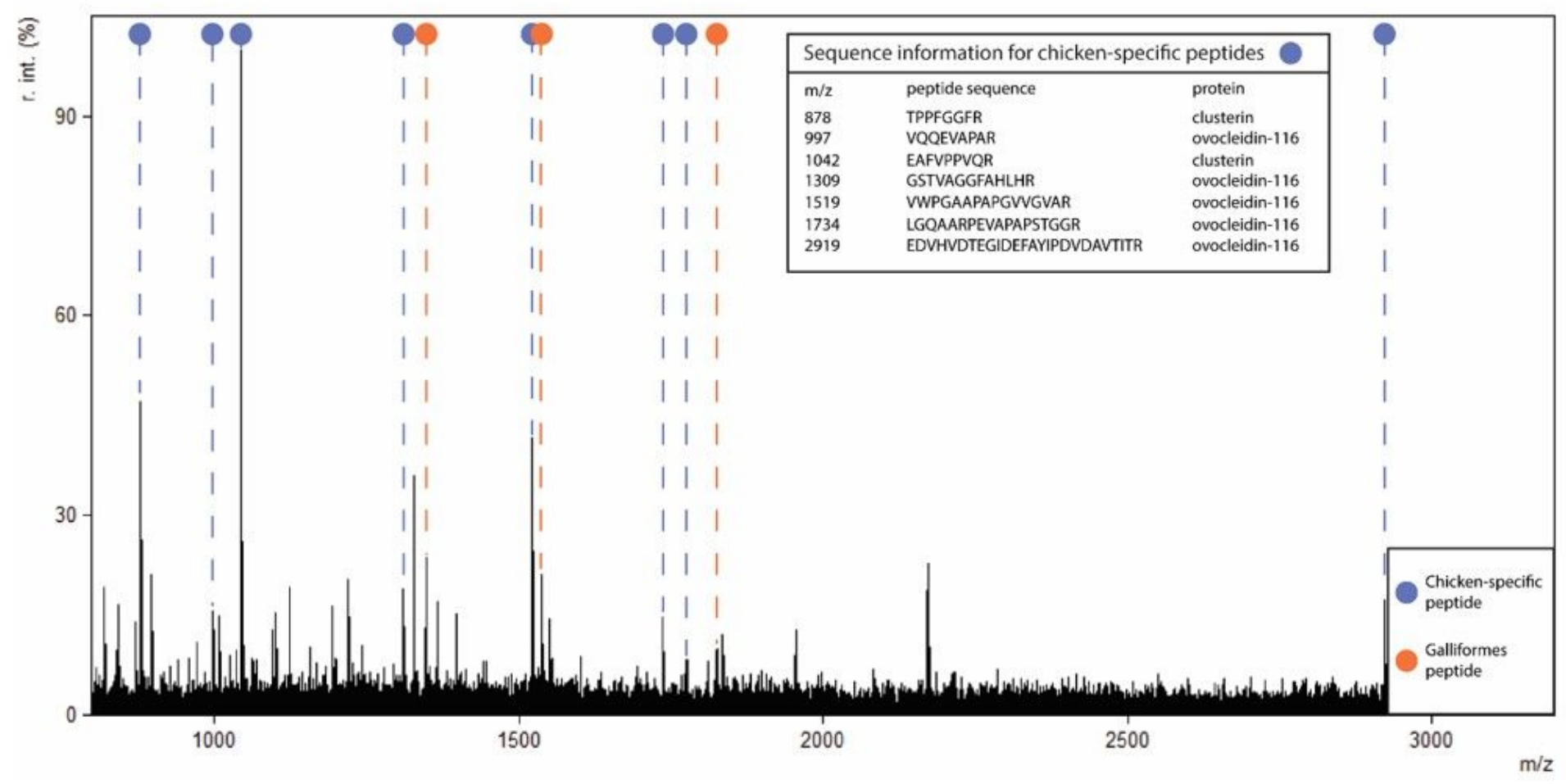

Figure 4

MALDI-ToF-MS spectra of sample CP565 from Afrasiab. The chicken-specific and Galliformes peptides identified in the sample are highlighted. Sequence information was taken from ${ }^{19}$.

\section{Supplementary Files}

This is a list of supplementary files associated with this preprint. Click to download.

- Petersetal.2022SIGuide.docx

- Petersetal.2022ExtendedDataTable1.png

- Petersetal.2022ExtendedDataTable2.png

- Petersetal.2022ExtendedDataTable3.png

- Petersetal.2022SupplementaryTable1.xlsx

- Petersetal.2022SupplementaryTable2.xlsx

- Petersetal.2022SupplementaryDiscussion.docx 